\title{
Pollutant Load Of Detergents In Tambak Wedi Urban Village, Kenjeran Subdistrict, Surabaya City In 2014
}

\author{
Edza Aria Wikurendra ${ }^{1}$ \\ Master Program Study, Environmental Health Departement, Public Health Faculty, University of Airlangga, \\ Surabaya, Indonesia ${ }^{1}$ \\ Email : edzaaria@gmail.com
}

\begin{abstract}
The increasing use of detergents as cleaning agents in the community potentially result in pollution of the water environment, this is supported by the quality of the well water having a high mineral hardness. When cleaning agents flow into waters through the river, it had a negative impact on the environment and health. The results showed that pollutant loads actually came from the use of detergent in 55 households at 0,323 $\mathrm{mg} / \mathrm{lt} / \mathrm{month}$ or $5,924 \mathrm{mg} / \mathrm{day}$, while the standard maximum pollutant load of detergent waste at 0,0016 $\mathrm{mg} / \mathrm{lt} / \mathrm{month}$ or $0,0292 \mathrm{mg} / \mathrm{day}$. The results concluded that the pollutant load value in this research was higher than maximum pollutant load value, suggesting that pollutant load of detergent waste provided high contribution to pollution of the land and waters in such area, thereby the surface water quality decreased ground water quality, incidence of some disease such as diarrhea, heavy metal poisoning and skin disease. Therefore, it is recommended that households use environment-friendly detergents because it is easier to biodegrade. They should make simple domestic waste treatment equipment using biofilter technique.
\end{abstract}

Keywords : Pollutant load

\section{INTRODUCTION \\ 1.1 Background}

Detergents is one of the cleaning and material pollution which widely used by domestic and industrial, in many kinds of and volume. Detergents category material the polluter from non point source, that is a source of pollution could not known for certain known for example captives whom i have caused from households, agricultural , sedimentation and materials the polluter other hard traced the source ${ }^{[1]}$. The use of detergents in people will be better along with the community income, seen from the use of detergents per capita in line with the gross domestic product (GDP) every year. Increase community income, then the detergent consumption also increased. Statistics years 1998, detergents consumption per capita is $1,97 \mathrm{~kg}$ on 1998 and 2,46 $\mathrm{kg}$ on 1997, but with the improvement of people's purchasing power detergent consumption increased to $2,11 \mathrm{~kg}$ on $1999,2,26 \mathrm{~kg}$ on 2001 and $2,32 \mathrm{~kg}$ on $2002^{[2]}$.

Brackish water is water that have salinitas between $0.5 \mathrm{ppt}$ s/d $17 \mathrm{ppt}$. This water many units in some regions like the estuaries (meetings sea water and fresh water) and coastal regions. Groundwater mixed by sea water contain many minerals like: Calcium Carbonate (CaCO3), Magnesium Carbonate (MgCO3) , Calcium Sulphate (CaSO4), Magnesium Sulfate (MgSO4) and so on. Mineral contained in brackish water caused by the sea water that contact with the rocks so that the water was widely containing minerals. Lots of water containing minerals calcium and magnesium known as hard water, namely water which is hard to use wash. Mineral hard water as ion $\mathrm{Ca}$ and $\mathrm{Mg}$ can react with anion soap, which would lower efficiency cleansing so it takes soap more to wash ${ }^{[3]}$, those compounds of calcium and magnesium relatively difficult to soluble in water, then tend to form the sediment or precipitates which finally become a crust.

The result of preliminary survey conducted, Head of Tambak Wedi Urban Village, Musdar, S.E said that although the majority of the community in Tambak Wedi Urban Village have get the service of PDAM Surya Sembada Surabaya but for domestic activities as washing clothes, washing dishes and activities associated by washing still use well water were at every houses. Supported by the water sample a well owned by residents to test laboratory, all of the water has high value hardness the $600 \mathrm{mg} / \mathrm{lt}$ and $570 \mathrm{mg} / \mathrm{lt}$. Overall water sample exceeds the maximum allowed namely $500 \mathrm{mg} / \mathrm{lt}$ according to PERMENKES no.416/menkes/per/ix/ 1990 about the terms and supervision water quality.

Based on the existing problems, how larger the burden on pollution in Tambak Wedi Urban Village due to use detergents. Then writers interested to conduct research with a title "Pollutant Load of Detergents in Tambak Wedi Urban Village, Kenjeran Subdistrict, Surabaya City in 2014”. 


\section{International Journal of Research in Advent Technology, Vol.5, No.7, July 2017 \\ E-ISSN: 2321-9637 \\ Available online at www.ijrat.org}

\subsection{Purpose}

To describe large pollutant load of detergents in Tambak Wedi Urban Village, Kenjeran Subdistrict, Surabaya City in 2014.

\section{LITERATURE REVIEW}

Detergents is cleaning media synthetic consisting of compounds capable of being extricated dirt, oil and kill bacteria useful and encourage growth algae if there are in sewage in into a body of water ${ }^{[4]}$. The application of detergents on the daily life of namely the process of leaching, for example in laundering clothing, laundering household appliances, cleaning on the material, etc. Application of detergents on the daily life of its mechanism estimated same with on industrial because a function of detergents the to remove impurities ${ }^{[5]}$

The waste disposal into the river/sources of water without treatment before, containing level pollutants organic high as well as affect conformity the waters of the for human use and stimulates growth algae and other aquatic plants. In addition a detergent in a body of water can damage gills and the organ of respiration fish resulting in tolerance fish to a body of water that the womb oksigennya low being declined. Fish need water that contains oxygen at least $5 \mathrm{mg}$ /quart or $5 \mathrm{ppm}$ ( art per million). When levels of oxygen less than $5 \mathrm{ppm}$, fish will die, but bacteria that the need for oxygen dissolve lower than $5 \mathrm{ppm}$ will grow. When the river of waste burning place containing material organic , most of oxygen dissolved used bacteria aerobic to oxidize carbon and nitrogen in organic matter into carbon dioxide and water. So that levels of oxygen dissolved will decrease rapidly and consequently animals like fish, shrimp and the shells will die ${ }^{[6]}$.

According to a Government Regulation No. 82 Year 2001 the pollution is the number of a pollutant contained in water or waste water. According to Djabu ${ }^{[7]}$ he burden of pollution is a material capacity the polluter multiplied the flow of water containing material the polluter, what this means is the number of heavy pollution in unit time certain, for example $\mathrm{kg} / \mathrm{day}$. The term burden pollution associated with the total number of the polluter or a mixture of pollution which to get in the neighborhood had direct or indirectly by an industry or group the industry in a particular area in a given time period. In the case of household wastes and the city, the burden of the term pollution linked to total waste to get in the neighborhood (directly or indirectly from city community during a specified time period).

\section{RESEARCH METHODS}

\subsection{Kind of research}

The kind of research this is a descriptive, in a survey that is described how larger the burden on the pollution in coastal areas. With the approach cross sectional, because the data was undertaken based on interviews and observation in the same time/simultaneously ${ }^{[8]}$.

\subsection{Population and Sample}

\subsubsection{Population}

Population in this research is all households in Tambak Wedi Urban Village, Kenjeran Subdistrict Surabaya City having well dig namely 121 households.

\subsubsection{Sample}

Sample in research is part of number of households in Tambak Wedi Urban Village, Kenjeran Subdistrict to know the use of pollution detergents in the area which use wells in the washing good washing clothes and others are at 55 households.

\subsection{Data Analysis}

Data analyzed by a sort of descriptive set presented in the form of narrations and table for analysis pollutan load uses the method volumetric based on Environmental Quality Waste Water for Industries and or Other Business Activities ${ }^{[9]}$.

\section{RESEARCH RESULTS AND DISCUSSION}

\subsection{The Number of Households Use Detergents}

The number of the use of detergents usually in Tambak Wedi Urban Village, Kenjeran Subdistrict Surabaya City total of 55 houses is as many as 5.033 gr/day. The use of detergents in Tambak Wedi Urban Village, Kenjeran Subdistrict Surabaya City an average of $91,059 \mathrm{gr} /$ day luminance house while for every $25 \mathrm{gr}$ can wash as many as $5 \mathrm{~kg}$ clothing and when the average the use of detergents every house of 91,059 gr/day so can wash as many as $18,301 \mathrm{~kg}$ laundry.

Levels of detergents high relative resulting in interference on the cutaneous surface directly or indirectly. Directly any skin disorder are in the form of the heat on the skin at the first contact with detergents where detergents containing $\mathrm{NaOH}$ contact with the increases the permeability the skin on old chemical due to the damaged stratum corneum in the skin as a result chemicals is easy to goes to the skin ${ }^{[10]}$. Indirectly is the use of detergents will cause symptoms when the was given in a long time and frequency of often ${ }^{[10]}$. So should be used detergents environmentally friendly in detergents where it contains $\mathrm{NaOH}$ a little order 


\section{International Journal of Research in Advent Technology, Vol.5, No.7, July 2017 \\ E-ISSN: 2321-9637 \\ Available online at www.ijrat.org}

to reduce effect posed as irritation in the skin at the use of the detergent.

\subsection{Discharge Emissions Waste Water Laundry}

Discharge waste water waste detergents issued by respondents surveyed is as many as 35,000 liters/day and samples to be taken in this research was as many as 55 houses. A discharge of water data issued during the process of leaching used for reckoning the burden of pollution the use of a detergent in the process of leaching. In the calculation of the burden pollution needed the average discharge the water used in any of the home where total discharge whole is divided with samples to be taken so obtained the results of 636,363 liters/day per house.

Pollutant load use of would influence the debits are issued. The bigger discharge captives whom $\mathrm{i}$ have caused issued pollution hence the burden of the higher. Burden pollution height could affect the quality of environment when material that flow to the waters through the rivers can make the impact negative with the environment and health. The least found a lot on the site of research is the contamination of river in the area. If concentration excess so bensen content in detergents will bersenyawa with chlorine that is in sea water, form a compound organoklorin that is carcinogen ${ }^{[11]}$.

\subsection{Pollutant Load of Detergents in Tambak Wedi Urban Village, Kenjeran Subdistrict, Surabaya City}

From scratch that has been done the results debits and pollutant load of detergents in Tambak Wedi Urban Village, Kenjeran Subdistrict, Surabaya City in 2014 namely :

Table 1. Discharge And Pollutant Load Of Detergents In Tambak Wedi Urban Village Kenjeran Subdistrict Surabaya City In 2014 Information :

BPM : The monthly maximum pollution load BPA : The burden of the actual pollution monthly BPMi : Maximum daily load of pollution BPAi : Pollution loads in fact daily

The pollution actually (BPA) larger than the maximum pollution (BPM). Of the result, it can be said that discharge and load waste pollution detergents contributed pollution of crimes against the environment to parameter $\mathrm{BOD}_{5}$.

The high burden pollution actually $\mathrm{BOD}_{5}$ compared with a load maximum pollution, shows that the capacity of the process of/the decipherment of degradation organic materials that is easily decomposes (biodegradable) naturally very limited. This was made possible by waste water use a detergent in the process of leaching necessary processing before entering the environment (a body of water/land). There needs to be supervision of laundering in the event that has characteristics brackish covering control over discharge waste water which dumped and reducing levels of detergents used. hen efforts of control over discharge waste water which dumped and reduction levels detergents used not overcome burden pollution then required products detergents is environmentally friendly accepted by a body of water and land.

\subsection{Analysis of the impact of the use of detergent pollution load on the environment and health disorders}

The result of the pollution load of wastewater indicates that the detergent exceeds the maximum limit load of pollution so that the waste water in washing process wastewater Tambak Wedi Urban Village Kenjeran Subdistrict Surabaya City a major contribution in polluting the land and waters. The two most important ingredients of the shaper and i.e. detergent surfactants builders, has identified the influence of direct and indirect against man and his environment. The research of Heryani and Puji ${ }^{[12]}$ getting results that nature takes 9 days to spell out $50 \%$ of waste detergent.

Other disadvantages of the use of detergent is the occurrence of the processes of eutrophication waters. This occurs because the use of detergents with a high phosphate content. Eutrophication poses for uncontrolled growth water hyacinth and cause the superficiality of the river. In contrast with low phosphate detergents are at risk of causing irritation to the hands and caustic, because of the known more alkalis. Acidic properties $(\mathrm{pH})$ levels between 10-12 ${ }^{[13]}$. Based on data obtained by respondents against interviews that most of respunden complained when washing the heat of her skin and contact with detergents. According to

\begin{tabular}{|c|c|}
\hline \multicolumn{2}{|c|}{$\begin{array}{l}\text { Number of laundering during } 1 \text { month }=12 \text { times } \\
\text { Number of laundering produced } 1 \text { month }=219,612 \mathrm{~kg} \\
\text { cloth. }\end{array}$} \\
\hline \multicolumn{2}{|c|}{ DISCHARGE LIQUID WASTE } \\
\hline \multicolumn{2}{|c|}{$\begin{array}{l}\text { Dp ( waste discharge measured })=35 \mathrm{~m}^{3} / \text { day } \\
\text { DA (the actual liquid waste discharge) }=420 \mathrm{~m}^{3} / \text { day } \\
\text { DM (maximum liquid waste discharge) }=3,513 \mathrm{~m}^{3} / \text { day }\end{array}$} \\
\hline \multicolumn{2}{|c|}{ LIQUID WASTE POLLUTION LOAD } \\
\hline Indicator & BOD $_{5}$ Parameters \\
\hline BPM & $0,0016 \mathrm{mg} / \mathrm{lt}$ \\
\hline BPA & $0,323 \mathrm{mg} / \mathrm{lt}$ \\
\hline BPMi & $0,0292 \mathrm{mg} /$ day \\
\hline BPAi & $5,924 \mathrm{mg} / \mathrm{day}$ \\
\hline
\end{tabular}

the terms of the medical disease associated with the 


\section{International Journal of Research in Advent Technology, Vol.5, No.7, July 2017 E-ISSN: 2321-9637 \\ Available online at www.ijrat.org}

use of detergent is a disease dermatis irritant contact.

Irritant contact dermatitis is an inflammatory reaction of the skin due to an ingredient that is in contact with the skin ${ }^{[10]}$. Irritant contact dermatitis causing ingredients it can be either physical, chemical, or biological [10]. Direct leaching process gives the consequence will be more frequent contact with ingredients that can cause contact dermatitis. The process of sorting the laundry includes washing, washing, rinsing and soaking. Each work process that allows respondents to contact with agents cause irritant contact dermatitis due to work.

\section{CONCLUSION}

1. The Use Of Detergent

The use of detergent Tambak Wedi Urban Village Kenjeran Subdistrict Surabaya City as much 5,033 gr/day or average as much as $91.059 \mathrm{gr} / \mathrm{day} /$ House, for the amount of clothes can be laundered every home is as much $18.301 \mathrm{~kg} /$ day.

2. Discharge of waste Detergent

Discharge wastewater generated in each process of leaching on the Tambak Wedi Urban Village Kenjeran Subdistrict Surabaya City of 35,000 litres/day, the average waste generated 636.363 liters/day/House so as to discharge liquid waste sebernarnya is 420 $\mathrm{m} 3 /$ day (standard that allowed > 3.513 m3/day)..

3. Waste Pollution Load Detergent

The burden of the actual pollution 0.323 $\mathrm{mg} / \mathrm{lt} / \mathrm{month}$ or $5.924 \mathrm{mg} /$ day (a standard that allowed > $0.0016 \mathrm{mg} / \mathrm{lt} / \mathrm{month}$ or $>0.0292$ $\mathrm{mg}$ /day). The actual pollution load values greater than the value of the maximum pollution load so that the burden of waste detergent pollution contributes to high contamination of soils and waters of the lowliest.

4. The Impact Of Waste Detergent

High pollution load resulted in some of the impact in the environment around them is reducing the quality of the surface water causing the death of fish in the waters, causing the process of eutrophication, the decline in the quality of groundwater, resulting in various diseases such as diarrhea, kasiogenik and the most suffered are skin diseases (irritant contact dermatitis) resulting from direct contact with the detergent.
6. SUGGESTION

1. For Local People

Use of environmentally friendly detergents to reduce the pollution that occurred.

2. For Local Health Agencies

Should be doing training on detergent wastewater treatment simply by using a biofilter media to reduce the burden of pollution received by the environmental community and raising awareness towards environmental health.

\section{REFERENCE}

[1] Susana, T. dan Suyarso, 2008. Penyebaran Fosfat dan Deterjen di Perairan Pesisir dan Laut sekitar Cirebon. Jawa Barat, Pusat Penelitian Oseanografi - LIPI. Oseanologi dan Limnologi di Indonesia 34 : 117-131.

[2] Bisnis Indonesia, 2004. Deterjen, Bisnis Raksasa yang Makin "Berbusa-busa". Bisnis Com.

[3] Effendi, H., 2003. Telaah Kualitas Air: Bagi Pengelolaan Sumber Daya dan Lingkungan Periaran. Yogyakarta, Kanisius.

[4] Pankratz, T., 2001. Environmental Engineering Dictionary and Directory. Florida, CRC Press LCC Bocar Raton.

[5] Warlina, L., 2004. Pencemaran Air : Sumber, Dampak, dan Penanggulangannya. Makalah Pribadi. Sekolah Pasca Sarjana, ITB, Bogor.

[6] Widiyani, P. 2010. Dampak Dan Penanganan Limbah Deterjen. Program Studi Kesehatan Masyarakat Veteriner Fakultas Kedokteran Hewan Institut Pertanian Bogor.

[7] Djabu, U. Koesmantoro, H. et al., 1990/1991. Pedoman Bidang Studi Pembuangan Tinja dan Air Limbah pada Institusi Pendidikan Sanitasi/Kesehatan Lingkungan. Jakarta, Departemen Kesehatan RI Pusat Pendidikan Tenaga Kesehatan.

[8] Notoatmodjo,Soekidjo, 2010. Metodologi Penelitian Kesehatan. Jakarta, Rineka Cipta.

[9] Peraturan Gubernur Jawa Timur, 2013. Pergub Jatim No.72. Tentang Baku Mutu Air Limbah Bagi Industri dan atau Kegiatan Usaha Lainnya.

[10] Afifah, A., 2012. Faktor-Faktor yang Berhubungan dengan Terjadinya Dermatitis Kontak Akibat Kerja pada Karyawan Binatu. Karya Tulis Ilmiah. Fakultas Kedokteran. Universitas Diponegoro, Semarang.

[11] Linfield, M., 1976. Anionic Surfactans. New York, Marcel Dekker. 
International Journal of Research in Advent Technology, Vol.5, No.7, July 2017 E-ISSN: 2321-9637

Available online at www.ijrat.org

[12] Heryani. A, Puji, H. 2008. Pengolahan Limbah Deterjen Sintetik dengan Trickling Filter. Skripsi. Program Studi Ilmu Lingkungan. Universitas Diponegoro, Semarang.

[13] Ahsan, S., 2005. Effect of Temperature on Wastewater Treatment with Natural and Waste Materials. Clean Technology Enviroment Policy. 7:198-202. 